\title{
Mandatory IFRS Adoption and Earnings Quality: Evidence from the UK
}

\author{
Mohammad Issa Almaharmeh ${ }^{1} \&$ Ra'ed Masa'deh ${ }^{2}$ \\ ${ }^{1}$ Department of Accounting, Faculty of Management and Finance, The University of Jordan, Aqaba Branch, \\ Jordan \\ ${ }^{2}$ Department of Management Information Systems, School of Business, The University of Jordan, Amman, \\ Jordan \\ Correspondence: Mohammad Issa Almaharmeh, Department of Accounting, Faculty of Management and Finance, \\ The University of Jordan, Aqaba Branch, Jordan. E-mail: m.almaharmeh@ju.edu.jo
}

Received: April 15, 2018 Accepted: September 20, 2018 Online Published: October 29, 2018

doi:10.5539/mas.v12n11p197 URL: https://doi.org/10.5539/mas.v12n11p197

\begin{abstract}
This study examines the effect of mandatory IFRS adoption on the quality of accounting earnings for the firms listed in London Stock Exchange. After examining 9056 firm year observations for the period from 1994 to 2013 the results suggest that the mandatory adoption of IFRS leads to higher earnings quality. This study extends the current literature that examines the consequences of mandating IFRS adoption in the UK and shows that adopting high quality accounting standards leads to high quality accounting numbers.
\end{abstract}

Keywords: mandatory adoption, IFRS, earnings quality, accruals quality, UK

\section{Introduction}

Prior research suggests that mandatory adoption of IFRS leads to high-quality accounting numbers. The proponents of IFRS adoption argue that it improves the quality and quantity of financial disclosure (Ru\& Baljit, 2018). This assertion is supported by empirical evidence that suggests IFRS adoption leads to high-quality earnings. For example, Houqe et al. (2012), and Barth et al. (2008) provide international evidence that IFRS adoption leads to higher quality accounting numbers. Consistent results from emerging market were provided by Ismail et al. (2013), where they find that IFRS adoption leads to higher earnings quality for Malaysian firms.In addition, other research documented an increase in the value relevance of accounting numbers following the adoption of IFRS. For instance, Devalle et al. (2010) find that the adoption of IFRS increases the value relevance of some adopting countries. Clarkson et al. (2011) document a decrease in the value relevance for the companies of Common Low Countries, while record an increase in the value relevance of accounting numbers for Code Low Countries, following the mandatory adoption of IFRS.

However, some researchers suggest that IFRS will increase managerial flexibility and discretion especially due to the lack of implementation guidance and poor enforcement (Ball et al., 2003; Leuz 2003; Ahmed, Neel, \& Wang 2013). Moreover, (Barth et al., 2008) suggest that, IFRS is expected to restrict accounting alternatives which may reduce the ability of firms' accounting numbers to better reflect the firm's economic condition and performance. In addition, it is argued that the inherent flexibility in the principles-based IFRS standards may provide more opportunities for firms' managers to manage their numbers (Daske et al., 2008). Consequently, it is also likely that the IFRS adoption may result in more accounting manipulation and thus lower earnings quality to some extent.The financial reporting environment of The United Kingdom (UK) changed significantly after 2005, when the adoption of IFRS becomes mandatory. Such IFRS adoption may affect earnings quality primarily through additional disclosure and improved comparability, which, in turn, are expected to increase reporting transparency. The proponents of IFRS adoption argue that IFRS improve transparency by increasing the quantity and quality of financial disclosure.

This paper contributes to the literature that examines the economic consequences of mandatory IFRS adoption. Brüggemann et al. (2012) mention that, most of the literature on the consequences of mandatory IFRS adoption provide transitory evidence with low statistical power because of short history of IFRS adoption, also, they mention that most of these papers provide evidence from cross-country studies which make it difficult to 
disentangle the effect of IFRS from other synchronous changes that may affect the financial reporting content. Following the recommendations of Brüggemann et al. (2012) this paper relied on data from one country for a long period after IFRS adoption to draw its results. Using a large sample of 9,049 firm year observations collected from 1385 distinct UK firms for the period from 1994 to 2013, the results suggest that mandatory IFRS adoption leads to increases in the earnings quality for the UK's firms. This result is robust after using different measure of earnings quality, and after using different tests models. Higher earnings quality numbers after the mandatory adoption of IFRS is in line with the view that higher quality accounting standards will lead to higher quality accounting numbers (Barth et al., 2008; Houqe et al., 2012; Ismail et al., 2013).

In Section 2, we set out the theoretical framework for the study and develop the hypothesis. In Section 3, we describe the sample selection and the measurements of variables used in the study. In Section 4, we discuss the research results. In Section 5, we conclude the results of the study.

\section{Prior Research and Hypothesis Development}

To address why IFRS adoption could lead to higher earnings quality, we turn to the large and growing body of literature that provide imperial evidence of the consequences of IFRS adoption. The proponents of IFRS adoption argue that IFRS improve transparency by increasing the quantity and quality of financial disclosure. The current combination of IASs and IFRSs has generated more than 2000disclosure requirements which preparers need to interpret and implement (Ernst \& Young, 2006). Further, these requirements represent twice the number of standards that were required under UK GAAP and four times those that had been required in France, which leads to increases of up to 30 per cent in the length of post-IFRS adoption annual reports for a sample of EU firms (Ernst \& Young, 2006). Moreover, Ball (2006) suggest that IFRS provides more accurate and timely financial statement information than any national standards, including the local standards of EU countries.

Consistent with the assertion that IFRS adoption improves the quality of financial disclosure; previous research finds that IFRS adoption has favorable capital market consequences. Barth et al., (2008); Devalle et al., (2010); Landsman et al. (2012); Tsalavoutas et al., (2012); Ismail et al., (2013); suggest an increase in the value relevance and information content of accounting numbers following the adoption of IFRS. In addition, Ballas et al., (2010); Barth et al., (2008); Doukakis, (2010); Houqe et al., (2012); Ismail et al., (2013), Aksu \& Espahbodi, (2012); and Daske \& Gebhardt, (2006) find that IFRS leads to high quality accounting numbers and improved disclosure quality. Similarly, Horton et al., (2013); and Houqe et al., (2014), provide evidence that IFRS adoption improve information environment through increasing analysts' forecast accuracy and reducing analysts' forecast dispersion.A reduction in information processing cost, crash risk, and cost of equity capital, following IFRS adoption are documented by (Armstrong et al., 2010; Daske et al., 2008; DeFond et al., 2011),(Mark L. DeFond et al., 2015), and (Daske et al., 2008; Kim, Shi, et al., 2014; Li, 2010; Palea, 2009), respectively. While increases in the informativeness of stock prices and the transparency and comparability of financial disclosure are suggested by (Beuselinck et al., 2010; Bissessur \& Hodgson, 2012; Gillberto Loureiro \& Taboada, 2012; Kim \& Shi, 2012a); and (Brochet et al., 2013).

However, the opponents of IFRS argue that IFRS has increased managerial flexibility and discretion especially due to the lack of implementation guidance and poor enforcement (Ball et al. 2003; Leuz 2003; Ahmed, Neel, \& Wang 2013). In, addition, limiting accounting alternatives may reduce the ability of firms' accounting numbers to reflect the firm's economic condition and performance (Barth et al., 2008). In addition, it is argued that the inherent flexibility in the principles-based IFRS standards may provide more opportunities for firms' managers to manage their numbers (Daske et al., 2008). Consequently, it is also likely that the IFRS adoption may result in more accounting manipulation and thus lower earnings quality to some extent.

Capkunet al. (2012) report an increase in earnings management from pre-2005 to post-2005 for early and late voluntary adopters in countries that allowed early IFRS adoption, and for mandatory adopters in countries that did not allow early IFRS adoption. Similarly, Ahmed et al. (2013) provide evidence suggesting that following the mandatory adoption of IFRS, income smoothing and accrual aggressiveness increase while timeliness of loss recognition decreases. Christensen et al. (2015) examine the effect of IFRS adoption on income smoothing for German firms and find that income smoothing decreased significantly under voluntary but not under mandatory IFRS adoption. They suggest that mandatory adopters might perceive fewer benefits from principles based set of accounting standards (i.e. IFRS) and thus avoid the costs of transferring to IFRS. Paananen (2008) and Paananen \& Lin (2009) both find a decrease in financial reporting quality, an increase in earnings management, and a reduction in timeliness of loss recognition, following IFRS adoption in Germany. Jeanjean \& Stolowy (2008) find no decline in the pervasiveness of earnings management in Austria and the United Kingdom and find an 
increase in France. Both Ahmed et al. (2013) and Chen et al. (2010) find evidence of income smoothing and a reduction in timeliness of loss recognition following mandatory IFRS. However, contrary to Chen et al. 2010, Ahmed et al. (2013) find a significant increase in aggressive reporting of some accruals and no reduction in the management of earnings towards a target. Prior studies therefore provide mix evidence about the net effect of IFRS adoption in earnings quality.

These mixed evidences could be explained by that some IFRS voluntary adopters may choose to adopt IFRS name without making any serious reporting changes (Daske et al., 2013). The fact that the results of the literature that examined the consequences of mandatory IFRS were driven from short history of mandatory IFRS adoption, reflecting a combination of idiosyncratic, temporary effects of first-time adoption and low statistical power due to relatively short analysis periods, two to three years after the mandatory adoption (Brüggemann et al., 2013), could explain also the inconsistent results of IFRS literature. As the net effect of IFRS adoption is ambiguous, we will re-examine the effect of IFRS on earnings quality by testing the following null hypothesis:

HO: The mandatory adoption of IFRS did not significantly affect the earnings quality of the UK firms.

\section{Sample and Methodology}

In this section, we describe our sample and the methodology used to test the hypothesis developed above. Section 3.1 briefly describes our data sources and the procedures followed in sample selection process, and Section 3.2 provides an overview of our design, along with a detailed description of our variables. We use a fixed effect design to test our predictions on the effect of mandatory IFRS adoption on earnings quality.

\subsection{Data}

The initial research sample consists of all the firms listed in London Stock Exchange that have available data in DataStream, Worldscope, and IBES international databases for the period between $1^{\text {th }}$ January 1994 and $31^{\text {st }}$ December 2013 (The three databases are combined in one software called DataStream published by Thomson Reuter). The sample period was chosen to cover the periods before the adoption and after the adoption, thus the effect of IFRS adoption on the earnings quality can be examined. We took long time period for two reasons. First, choosing a long period before and after IFRS adoption could result in a better measure of the effect of IFRS adoption on earnings quality. Since taking a long period before the adoption provides a better measure of the average earnings quality levels before the mandatory adoption of IFRS. Second, Wang \& Yu (2015) suggest that one of the advantages of taking a large sample for a longer time period is that the results and conclusions, drawn from this sample, are more representative. The investigation is undertaken in one country, the UK, to hold constant certain institutional factors such as stock listing requirements, accounting disclosure requirements, market microstructures and regulatory environments that may confound the results, thereby strengthening the reliability of our findings, as suggested by Ruland et al. (2007), andPaananen \& Lin (2009). In addition, according to Schipper (2005)choosing one country instead of multi countries helps in minimizing the heterogeneity and the cross-countries differences that may have an effect on the dependent variable.

Only firms listed in the L.S.E, active and dead, with available data for the period from 1990 to 2013 were included in the sample. Following the prior research (Hutton et al., 2009; Kim \& Shi, 2012) the firms in financial, banking, and insurance industries, with SIC code 6000-6999 were excluded from the sample, because these industries have special regulations and financial accounting standards and the inclusion of these industries in the sample may distort the research results. Any firms with unavailable data to calculate the explanatory variables, and the dependent variablewere excluded from the sample also. After applying the previous procedures, the final sample consists of 9049 firm-year observations collected from 1385 distinct UK firms for the period from 1994 to 2013 .

\subsection{Methodology and Variable Measurement}

We estimate fixed effect regression model and perform robustness analyses to test the hypothesis as follows:

To test $\mathrm{H} 1$ we specifying the following regression model:

$$
\begin{gathered}
M J_{-} \text {Model }_{i, t} \\
\varepsilon_{i, t}
\end{gathered} \quad \alpha_{0}+\beta_{1} I F R S_{i, t}+\beta_{2} L E V_{i, t}+\beta_{3} M \backslash B_{i, t}+\beta_{4} S I Z E_{i, t}+\beta_{5} R O A_{i, t}+\text { Industryfixedeffect }+
$$

In our robustness test we used different measure of earnings quality and estimate different regression models to examine the effect of IFRS adoption on earnings quality.

\subsection{Earnings Quality Measures}

Given the fact that, the accruals quality models have been shown to be the most popular model in measuring 
earnings quality, where(Dechow et al., 2010)reviewed more than 300 papers on earnings management determinants and consequences, and claims that the Jones (1991) Model, and the Modified Jones (1995) Model, are the top two in the list of the most commonly used measures of earnings quality. The measurement of earnings quality related to accruals quality is used in this study.Using accruals quality as a measure of earnings quality is consistent with previous research in this area, including Rajgopal and Venkatachalam (2011), Mouselli, Jaafar, \& Hussainey (2012), Ismail et al. (2013), and Doukakis (2014), Watrin \& Ullmann (2012), Hutton et al. (2009) and Kothari et al. (2005).

FollowingKothari et al. (2005), the equation for nondiscretionary accruals for the Modified Jones Model (1995) is expressed as follows:

$$
\operatorname{NDACC}_{i, t}=\alpha_{i, t} 1 / L T A+\alpha_{1}\left(\Delta R E V_{i, t}-\Delta R E C_{i, t} / L T A_{i, t}\right)+\alpha_{2} P P E_{i, t} / L T A_{i, t}
$$

Where

$\mathrm{NDACC}_{\mathrm{i}, \mathrm{t}}=$ non-discretionary accruals for firm i in year $\mathrm{t}$.

$\mathrm{LTA}_{\mathrm{i}, \mathrm{t}}=$ lagged total assets for firm $\mathrm{i}$ in year t.1

$\Delta \mathrm{REV}_{\mathrm{i}, \mathrm{t}}=$ change in revenues for firm $\mathrm{i}$ in year $\mathrm{t}$.

$\Delta \mathrm{REC}_{\mathrm{i}, \mathrm{t}}=$ change in account receivable for firm $\mathrm{i}$ in year $\mathrm{t}$.

$\mathrm{PPE}_{\mathrm{i}, \mathrm{t}}=$ property, plant and equipment for firm $\mathrm{i}$ in year $\mathrm{t}$.

To calculate the nondiscretionary accruals using the Modified Jones Model (1995), it is necessary to estimate the coefficients $\alpha_{i, t}, \alpha_{1}$, and $\alpha_{2}$, for the above model. The ordinary least squares regression was used to estimate the coefficients for each industry in each year to partially controls for industry level changes in economic conditions, that affect total accruals and allows the coefficients to vary across time (Doukakis, 2014)

Consistent with the approach used by Athanasakou, Strong, \& Walker (2009), industries with less than six observations in each year were removed from the sample, because of the lack of quorum in calculating the coefficient. The industry classification was based on the two digits SIC code classification.

In order to obtain the coefficients for the model in e.q (1),we estimate the following cross-sectional regression model using the firms in each two digit SIC code for each year between 1994 and 2013:

$$
\frac{T A_{i, t}}{L T A_{i, t}}=\alpha\left(\frac{1}{L T A_{i, t}}\right)+\alpha_{1} \frac{\left(\Delta R E V_{i, t}\right)}{L T A_{i, t}}+a_{2}\left(\frac{P P E_{i, t}}{L T A_{i, t}}\right)+\varepsilon_{i, t}
$$

Where:

$T A_{i, t}=$ total accrual for firm $i$ in year $t$.

$L T A_{i, t}=$ lagged total asset for firm $i$ in year $t$.

$\triangle R E V_{i, t}=$ change in revenues for firm $i$ in year $t$.

$P P E_{i, t}=$ property, plant and equipment for firm $i$ in year $t$.

The coefficient from this regression model is used to calculate the nondiscretionary accruals (NDACC) based on the Modified Jones (1995) Model and the Jones (1991) model. Finally, the discretionary (abnormal) accruals calculating the difference between total accruals and the fitted normal accruals as follows:

$$
A A C_{i, t}=\left(T A_{i, t} / \mathrm{LTA}\right)-N D A C C_{i, t}
$$

All the variables are divided by lagged total assets to reduce hetroscedasticity(Jones, 1991).

Where:

$\mathrm{AAC}_{\mathrm{i}, \mathrm{t}}=$ abnormal accruals for firm $\mathrm{i}$ in year $\mathrm{t}$.

$\mathrm{TA}_{\mathrm{i}, \mathrm{t}}=$ total accrual for firm $\mathrm{i}$ in year $\mathrm{t}$.

$\mathrm{LTA}_{\mathrm{i}, \mathrm{t}}=$ lagged total asset for firm $\mathrm{i}$ in year $\mathrm{t}$.

NDACC $_{i, t}=$ non-discretionary accruals for firm $i$ in year $t$.

The earnings quality for each firm is estimated through the absolute value of the abnormal accruals $\left(\left|A A C_{i, t}\right|\right)$. The large quantity of absolute value of abnormal accruals indicates low earnings quality and vice versa.

\subsection{IFRS Definition}

The information about the accounting standards followed in preparing the firm's financial statements was obtained 
from DataStream database. The DataStream code (WC07536) provides information about the accounting standards followed in preparing the financial statements for a specific firm. Table 1 provides a detailed description of the Worldscope code (WC07536) classification of the accounting standards followed by each firm. DataStream identifies 23 different accounting standards that are used by firms to prepare the financial statements. This identification ranges from local accounting standards $(07536=1)$, International Accounting Standards (IAS) pronounced by International Accounting Standards Committee IASC $(07536=2)$, U.S. standards $(07536=3)$, accounting standards that adopt local standards with other gridlines $(07536=08,10,17)$, or other hybrid type accounting standards that adopt local standards along with international accounting standards $(07536=18,19)$. The information about Worldscope accounting standards classifications is retrieved from Thomson Reuters (2012) website.This research follows Kim \& Shi (2012a), by identifying the firm as an IFRS adopter, if it adopts a full set of IFRS or IAS ( $07536=02$ or 23$)$, and marked as a non-adopter if it adopts any other accounting standards. In particular, if the firm adopts IAS or IFRS with another set of accounting standards, then this firm is considered as a non-adopter.

\subsection{Control Variables}

We include in the regression model several control variables that previous literature finds or suggests a relationship between these variables and earnings quality.Firm size, as measured by firm's total asset, is expected to influence earnings quality. McInnis \& Collins (2011) expect that firm size could have a negative effect on earnings quality.

\subsubsection{Size}

Watts \& Zimmerman (1978) suggest that large firms face greater political costs relative to small firms since larger firms are expected to be followed by more financial analysts and investors due to their larger market value and, hence, greater influence on the market. If this is true, then larger companies would have a greater incentive to reduce earnings. In addition, Lobo \& Zhou (2006) note that large firms may have more opportunities to overstate earnings because of the complexity of their operations and the difficulty for users to detect overstatement. Either way, size is a variable that could potentially bias the coefficients of the variables of interest in the study. Hence, we include a size variable to control for potential earnings overstatement.

Table 1. Worldscope description of accounting followed (Field 07536)

\begin{tabular}{ll}
\hline Worldscope fields 07536 & Worldscope description \\
\hline 1 & Local standards \\
2 & International standards \\
3 & U.S. standards (GAAP) \\
4 & Commonwealth countries standards \\
5 & EU standards \\
6 & International standards and some EU guidelines \\
7 & Specific standards set by the group \\
8 & Local standards with EU and IASC guidelines \\
9 & Not disclosed \\
10 & Local standards with some EU guidelines \\
11 & Local standards - inconsistency problems \\
12 & International standards - inconsistency problems \\
13 & US standards - inconsistency problems \\
14 & Commonwealth standards - inconsistency problems \\
15 & EEC standards - inconsistency problems \\
16 & International standards and some EU guidelines - inconsistency problems \\
17 & Local standards with some OECD guidelines \\
18 & Local standards with some IASC guidelines \\
\hline
\end{tabular}




\begin{tabular}{ll}
\hline 19 & Local standards with OECD and IASC guidelines \\
20 & US GAAP reclassified from local standards \\
21 & Local standards with a certain reclassification for foreign companies \\
22 & Other \\
23 & IFRS \\
\hline
\end{tabular}

\subsubsection{Growth Opportunity}

Following the outcomes of An \& Zhang (2013), Bae et al. (2013), Hasan et al. (2014), He et al. (2013), Gul et al. (2010), and Hutton et al. (2009)the growth opportunity is calculated as the ratio of market value of equity to book value of equity. Summers \& Sweeney (1998) note that unethical managers may be induced to misstate financial statements when growth slows or reverses, in order to maintain the appearance of consistent growth. The market to book ratio represents market expectations of future profitability growth. Trying to meet such expectations could be a major motive for managers and discretionary accruals is a useful tool to attain that objective. McInnis \& Collins (2011) suggest that firms with higher market-to-book ratios (MTB) have greater incentives to meet earnings targets, so we expect MTB to have negative effect on earnings quality.

\subsubsection{ROA}

Firm's performance and profitability, as measured by the ratio of net income to total assets (Ben-Nasr \& Cosset, 2014; and Gul, Srinidhi, et al. 2011)is believed to have an effect on earnings quality. We include ROA in the regression to control for differences in performance between firms across the sample because prior research documents a relation between abnormal accruals and performance (e.g., Dechow et al., 1995; McInnis \& Collins, 2011). Additionally, Kothari et al. (2005) offer evidence that controlling for ROA reduces the probability of Type I error in earnings quality studies where performance differences are not part of the hypotheses being tested.

\subsubsection{Leverage}

Leverage is measured as the ratio of total liabilities to total assets and is included to control for the possible effects (positive or negative) of firm risk. Velury \& Jenkins (2006) and Eng \& Mak (2003) find that managerial ownership and debt (firm size) are negatively (positively) related to disclosure quality. DeFond \& Jiambalvo (1994) presents evidence that managers of highly leveraged firms have incentives to make income increasing discretionary accruals to avoid debt covenant violation. Based on the previous discussion we expect leverage to have positive effect on abnormal accruals.

\section{Discussion of Results}

\subsection{Descriptive Statistics and Correlation Test}

Table (2) presents descriptive statistics for the variables used in our analysis. The mean and median for the discretionary (abnormal) accruals, using Modified Johns model, are $6.36 \%$ and $3.95 \%$ of total assets, respectively. These values are comparable to that in earnings quality literature. Iatridis (2012) in his UK study find that the average value of discretionary accruals using Jones (1991) model is about 6\%. The statistics for other variables is as follow; growth opportunity (as measured by market value of equity to book value of equity) range from -7.3 to 27.85 with a mean value 3.043. Leverage, size, and ROA record a mean (median) value of, 0.201 (0.172), $11.790(11.566)$, and $0.013(0.043)$, respectively.

Table 2 present the descriptive statistics for the variable of interest. The statistics are computed from 9049 firm year in the sample period 1994-2013

\begin{tabular}{ccccccc}
\hline & Num. of Obs & MEAN & STD.DEV. & MIN & MAX & median \\
ABS_JOHNS & 9049 & 0.062 & 0.0668 & 0.0002 & 0.31 & 0.039 \\
ABS_MJOHNS & 9049 & 0.064 & 0.0725 & 0.001 & 0.349 & 0.039 \\
GROWTH_OPPURTUNITY & 9049 & 3.043 & 4.527 & -7.3 & 27.85 & 1.93 \\
LEVERAGE & 9049 & 0.201 & 0.1841 & 0.0001 & 3.714 & 0.172 \\
SIZE & 9049 & 11.79 & 2.2204 & 0 & 19.414 & 11.566 \\
ROA & 9049 & 0.013 & 0.2401 & -1.308 & 0.943 & 0.043
\end{tabular}




\begin{tabular}{llllll} 
IFR & 9049 & 0.577 & 0.494 & 0 & 1 \\
\hline
\end{tabular}

Table (3) Presents Pearson correlation matrix for the dependent (earnings quality), independent (IFRS adoption) and all the control variables used in the regression analysis. The Pearson correlation coefficient is a measure of the strength of the linear relationship between two variables. The highest correlation coefficient is between growth opportunity and leverage, and the lowest correction is between ROA and IFRS. The correlation between IFRS adoption and abnormal accruals is negative suggesting that the IFRS adoption could lead to higher earnings quality. Because the correlation coefficients for all the variables in the correlation analysis matrix are below $80 \%$, we can suggest that there is no multicollinearity problem in the data (Gujarati \& Porter, 2009; Hair et al., 2010).

Table 3. Reports the correlation coefficient between key variables; the correlations are computed from 9049 firm year in the sample period 1994-2013.

\begin{tabular}{|c|c|c|c|c|c|c|}
\hline & ABS_MJONS & GROWTH_OPPORTUNITY & LEVERAGE & SIZE & ROA & IFRS \\
\hline ABS_MJONS & 1 & & & & & \\
\hline GROWTH_OPPORTUNITY & 0.0507 & 1 & & & & \\
\hline LEVERAGE & 0.062 & -0.716 & 1 & & & \\
\hline SIZE & -0.1404 & -0.0704 & 0.1357 & 1 & & \\
\hline ROA & -0.2594 & -0.0875 & -0.1049 & 0.3377 & 1 & \\
\hline IFRS & -0.038 & -0.0977 & 0.0237 & 0.0819 & -0.0064 & 1 \\
\hline
\end{tabular}

\subsection{Main Results}

Table 4 (Modified Johns model) Fixed effect model with adjusted standard error for hetroscedasticity.

Table 4. Multivariate regression analysis of IFRS adoption and earnings quality. The sample consists of 9049 firm year observations from 1385 UK listed firms for the period between 1994 and 2013. This regression results based on panel data industry fixed effect model. The dependent variable is earning quality calculated by Modified Johns model. The main independent variable is the mandatory adoption of IFRS; the first column presents the dependent variables. The second column presents the estimated coefficients change in the dependent variable as a result of one unit change in the independent variable. The third, fourth and fifth columns represent the standard errors, $\mathrm{t}$ _test and $\mathrm{p}_{-}$value results respectively. Here ${ }^{*},{ }^{* *}, * * *$ present $10,5,1 \%$ levels of significant respectively for two tailed test

\begin{tabular}{lllll}
\hline & coef. & std.err & $\mathrm{t}$ & $\mathrm{p}$ \\
\hline GROWTH_OPPORTUNITY & 0.0002 & 0.0002 & 0.89 & 0.372 \\
LEVERAGE & 0.0051 & 0.0076 & 0.67 & 0.5 \\
SIZE & -0.0048 & 0.0018 & -2.68 & $0.007^{* * * *}$ \\
ROA & -0.6382 & 0.0090 & -7.07 & $0^{* * *}$ \\
IFRS & -0.0072 & 0.0021 & -3.47 & $0.001^{* * *}$ \\
Const & 0.1222 & 0.021 & 5.82 & $0^{* * *}$ \\
\hline
\end{tabular}

The significant negative effect of IFRS variable on abnormal accruals is consistent with the assertion that IFRS adoption improves the quality of financial disclosure. Previous research finds that IFRS adoption has favorable capital market consequences. (Barth et al., 2008; Devalle et al., 2010; Ismail et al., 2013; Tsalavoutas et al., 2012, Landsman et al., 2012) suggest an increases in the value relevance and information content of accounting numbers following the adoption of IFRS. In addition, (Ballas et al., 2010; Barth et al., 2008; Doukakis, 2010; Houqe et al., 2012; Ismail et al., 2013, Aksu \& Espahbodi, 2012; Daske \& Gebhardt, 2006) find that IFRS leads to high quality accounting numbers and improved disclosure quality. Similarly, (Horton et al., 2013; Houqe et al., 2014), provide evidence that IFRS adoption improve information environment through increasing analysts' 
forecast accuracy and reducing analysts' forecast dispersion.

Prior research suggests that mandatory adoption of IFRS adoption leads to high-quality accounting numbers. For example, Houqe et al. (2012), and Barth et al. (2008) provide international evidence that IFRS adoption leads to higher quality accounting numbers. Consistent results from emerging markets were provided by Ismail et al. (2013). In addition, other research documented an increase in the value relevance of accounting numbers following the adoption of IFRS. For example, Devalle et al. (2010) and Clarkson et al. (2011) find that the adoption of IFRS increases the value relevance for some adopting countries. Based on previous discussion one can expect higher levels of earnings quality following the mandatory adoption of IFRS. There is a positive effect of leverage on discretionary accruals, this mean that high leverage leads to lower earnings quality. This result is consistent with the results of Velury \& Jenkins (2006) and Eng \& Mak (2003) who find that debt is negatively related to disclosure quality. DeFond \& Jiambalvo (1994) presents evidence that managers of highly leveraged firms have incentives to make income increasing discretionary accruals to avoid debt covenant violation.

Consistent with the expectation, we find a positive association between MTB and discretionary accruals. This result is in line with McInnis and Collins (2011) who suggest that firms with higher market-to-book ratios (MTB) have greater incentives to meet earnings targets. Firms' size shows negative effect on abnormal accruals. This result suggests that big firms tend to have higher quality earnings numbers. The results is consistent with the results of Christensen et al. (2015), andFang, Huang, \& Karpoff (2016). The significant negative effect of ROA on discretionary accruals suggests that, more profitable firms have higher quality earnings numbers.

\subsection{Robustness Tests}

Our results are robust after using different models and after using different measures of earnings quality. We repeat the regression by using pooled OLS regression, and fixed effect model with hetroscedasticity adjusted standard error and the results are robust. In addition, we repeat the regression by using earnings quality as measured by John's model, and using OLS, fixed effect model, and fixed effect model with hetroscedasticity adjusted standard error, and the results were consistent with our main regression results. All the tables for robustness test can be found in the appendix.

\section{Summary and Conclusion}

This study investigates the impact of the mandatory adoption of IFRS on the earnings quality of the UK firms. Using a sample of 9049 firm year observations collected from 1385 distinct firms, we run regression analyses to compare those firms' earnings quality between the pre- and post-IFRS periods. The regression results suggest that earnings quality, as measured by discretionary accruals did improved following the mandatory adoption of IFRS. This research documents clear and novel evidence on whether the mandatory adoption of IFRS improved the earnings quality of the UK firms. The study findings may provide implications to the users of accounting information and the standard setters. It is clear that the IFRS adoption has improved firm's accruals quality, so it could benefit accounting information users in this respect. The findings may also help the standard setters in the UK in considering whether or not to adopt IFRS for UK's private firms in the future. Hence, the results can serve as a piece of timely evidence for evaluating the IFRS adoption in the UK.

In addition, this paper contributes to the literature that examines the economic consequences of mandatory IFRS adoption. Most of the literature on the consequences of mandatory IFRS adoption provide transitory evidence with low statistical power because of short history of IFRS adoption Brüggemann et al. (2012).Also, most of these papers provide evidence based on multi-countries data which make it difficult to distinguish the effect of IFRS from other concurrent changes that may affect the financial reporting content. By using large sample for long time period, from one county, we followed the future research recommendations ofBrüggemann et al. (2012).

\section{References}

Ahmed, A., Neel, M., \& Wang, D. (2013). Does mandatory adoption of IFRS improve accounting quality? Preliminary evidence. Contemporary Accounting Research, 30, 1344-1372.

Aksu, M. H., \& Espahbodi, H. (2012). Impact of IFRS adoption and corporate governance principles on transparency and disclosure: the case of Istanbul stock exchange. Emerging Markets Finance and Trade.

American Psychological Association. (1972). Ethical standards of psychologists. Washington, DC: American Psychological Association.

An, H., \& Zhang, T. (2013). Stock price synchronicity, crash risk, and institutional investors. Journal of Corporate Finance, 21, 1-15. http://dx.doi.org/10.1016/j.jcorpfin.2013.01.001 
Armstrong, C. S., Barth, M. E., Jagolinzer, A. D., \& Riedl, E. J. (2010). Market reaction to the adoption of IFRS in Europe. Accounting Review, 85(1), 31-61.

Athanasakou, V. E., Strong, N. C., \& Walker, M. (2009). Earnings management or forecast guidance to meet analyst expectations? Accounting and Business Research, 39(1), 3-35. http://dx.doi.org/10.1080/00014788.2009.9663347

Bae, K. H., Kim, J. M., \& Ni, Y. (2013). Is firm-specific return variation a measure of information efficiency?. International Review of Finance, 13(4), 407-445. http://dx.doi.org/10.1111/irfi.12016

Ball, R. (2006). International Financial Reporting Standards (IFRS): Pros and cons for investors. Accounting \& Business Research (Wolters Kluwer UK), 36, 5-27.

Ball, R., Robin, A., \& Wu, J. (2003). Incentives versus standards: Properties of accounting income in four East Asian countries and implications for the acceptance of IAS. Journal of Accounting and Economics, 36(1-3), 235-270.

Ballas, A., Skoutela, D., \& Tzovas, C. (2010). The relevance of IFRS to an emerging market: Evidence from Greece. Managerial Finance, 36(11), 931-948. http://dx.doi.org/10.1108/03074351011081259

Barth, M. E., Landsman, W. R., \& Lang, M. H. (2008). International accounting standards and accounting quality. Journal of Accounting Research, 46(3), 467-498. http://dx.doi.org/10.1111/j.1475-679X.2008.00287.x

Beuselinck, C., Joos, P., Khurana, I. K., \& Van der Meulen, S. (2010). Mandatory IFRS reporting and stock price informativeness. Tilburg University.

Bissessur, S., \& Hodgson, A. (2012). Stock market synchronicity-An alternative approach to assessing the information impact of Australian IFRS. Accounting \& Finance, 52(1), $187-212$. http://dx.doi.org/10.1111/j.1467-629X.2010.00388.x

Brochet, F., Jagolinzer, A. D., \& Riedl, E. J. (2013). Mandatory IFRS Adoption and Financial Statement Comparability. Contemporary Accounting Research/Recherche Comptable Contemporaine, 30(4), 1373-1400.

Brüggemann, U., Hitz, J. M., \& Sellhorn, T. (2013). Intended and unintended consequences of mandatory IFRS adoption: A review of extant evidence and suggestions for future research. European Accounting Review, 22(1), 1-37.

Capkun, V., Collins, D., \& Jeanjean, T. (2012). Does adoption of IAS/IFRS deter earnings management?. Working Paper, HEC Paris, University of Iowa, ESSEC Business School.

Chen, H., Tang, Q., Jiang, Y., \& Lin, Z. (2010). The role of international financial reporting standards in accounting quality: Evidence from the European Union. Journal of International Financial Management\& Accounting, 21(3), 220-278.

Clarkson, P., Hanna, J. D., Richardson, G. D., \& Thompson, R. (2011). The impact of IFRS adoption on the value relevance of book value and earnings. Journal of Contemporary Accounting \& Economics, 7(1), 1-17. http://dx.doi.org/10.1016/j.jcae.2011.03.001

Daske, H., \& Gebhardt, G. (2006). International financial reporting standards and experts' perceptions of disclosure quality. Abacus, 42(3-4), 461-498. http://dx.doi.org/10.1111/j.1467-6281.2006.00211.x

Daske, H., Hail, L., Leuz, C., \& Verdi, R. (2008). Mandatory IFRS reporting around the world: Early evidence on the economic consequences. Journal of Accounting Research, 46(5), 1085-1142. http://dx.doi.org/10.1111/j.1475-679X.2008.00306.x

Daske, H., Hail, L., Leuz, C., \& Verdi, R. (2013). Adopting a label: Heterogeneity in the economic consequences around IAS/IFRS adoptions. Journal of Accounting Research, 51(3), 495-547.http://onlinelibrary.wiley.com/journal/10.1111/\%28ISSN\%291475-679X/issues

Dechow, P., Ge, W., \& Schrand, C. (2010). Understanding earnings quality: A review of the proxies, their determinants and their consequences. Journal of Accounting and Economics, 50(2-3), 344-401. http://dx.doi.org/10.1016/j.jacceco.2010.09.001

Dechow, P., Sloan, R., \& Sweeney, A. (1995). Detecting earnings management. The Accounting Review, 70(2), 193-225.http://dx.doi.org/10.2307/248303

DeFond, M., Hu, X., Hung, M., \& Li, S. (2011). The impact of mandatory IFRS adoption on foreign mutual fund ownership: The role of comparability. Journal of Accounting and Economics, 51(3), 240-258. 
http://dx.doi.org/10.1016/j.jacceco.2011.02.001

DeFond, M., Hung, M., Li, S., \& Li, Y. (2015). Does mandatory IFRS adoption affect crash risk? The Accounting Review, 90(1), 265-299. http://dx.doi.org/10.2308/accr-50859

DeFond, M., \& Jiambalvo, J. (1994, January). Debt covenants effects and the manipulation of accruals. Journal of Accounting and Economics, 17, 145-176.

Devalle, A., Onali, E., \& Magarini, R. (2010). Assessing the value relevance of accounting data after the introduction of IFRS in Europe. Journal of International Financial Management \& Accounting, 21(2), 85-119. http://dx.doi.org/10.1111/j.1467-646X.2010.01037.x

Doukakis, L. C. (2010). The persistence of earnings and earnings components after the adoption of IFRS. Managerial Finance, 36(11), 969-980. http://dx.doi.org/10.1108/03074351011081286

Doukakis, L. C. (2014). The effect of mandatory IFRS adoption on real and accrual-based earnings management activities. Journal of Accounting and Public Policy, 33(6), 551-572. http://dx.doi.org/10.1016/j.jaccpubpol.2014.08.006

Ernst, \& Young. (2006). IFRS: Observations on the implementation of IFRS. Ernst \& Young Publications. Retrieved

from http://www2.eycom.ch/publications/items/ifrs/single/200609_observations_on_ifrs/200609_EY_Observatio ns_on_IFRS.pdf

Eng, L., \& Mak, Y. (2003). Corporate governance and voluntary disclosure.J. Account. Publ. Pol. 22, 325-345

Fang, V. W., Huang, A. H., \& Karpoff, J. M. (2016). Short selling and earnings management: A controlled experiment. The Journal of Finance, 71(3), 1251-1294. http://dx.doi.org/10.1111/jofi.12369

Gillberto Loureiro, \& Taboada, A. G. (2012). The impact of IFRS adoption on stock price informativness. European Financial Management Association, 2012 Annual meeting, June 2012, Barcelona, Spain.

Gul, F. A., Kim, J. B., \& Qiu, A. A. (2010). Ownership concentration, foreign shareholding, audit quality, and stock price synchronicity: Evidence from China. Journal of Financial Economics, 95(3), 425-442. http://dx.doi.org/10.1016/j.jfineco.2009.11.005

Gujarati, D. N., \& Porter, D. (2009). Basic econometrics. Mc Graw-Hill International Edition.

Hair, J. F., Black, W. C., Babin, B. J., Anderson, R. E., \& Tatham, R. L. (2010). Multivariate data analysis (7th ed.), Pearson.

Hans, B., Christensen, Edward Lee, Martin Walker \& Cheng Zeng (2015). Incentives or standards: What determines accounting quality changes around IFRS adoption? European Accounting Review, 24(1), 31-61, http://dx.doi.org/10.1080/09638180.2015.1009144.

Hasan, I., Song, L., \& Wachtel, P. (2014). Institutional development and stock price synchronicity: Evidence from China. Journal of Comparative Economics, 42(1), 92-108. http://dx.doi.org/10.1016/j.jce.2013.07.006

He, W., Li, D., Shen, J., \& Zhang, B. (2013). Large foreign ownership and stock price informativeness around the world. Journal of International Money and Finance, 36, 211-230. http://dx.doi.org/10.1016/j.jimonfin.2013.04.002

Horton, J., Serafeim, G., \& Serafeim, I. (2013). Does mandatory IFRS adoption improve the information environment? Contemporary Accounting Research, 30(1), 388-423. http://dx.doi.org/10.1111/j.1911-3846.2012.01159.x

Houqe, M. N., Easton, S., \& van Zijl, T. (2014). Does mandatory IFRS adoption improve information quality in low investor protection countries? Journal of International Accounting, Auditing and Taxation, 23(2), 87-97.http://dx.doi.org/10.1016/j.intaccaudtax.2014.06.002

Houqe, M. N., van Zijl, T., Dunstan, K., \& Karim, A. K. (2012). The effect of IFRS adoption and investor protection on earnings quality around the world. The International Journal of Accounting, 47(3), 333-355. http://dx.doi.org/10.1016/j.intacc.2012.07.003

Hutton, A. P., Marcus, A. J., \& Tehranian, H. (2009). Opaque financial reports, R2, and crash risk. Journal of Financial Economics, 94(1), 67-86.http://dx.doi.org/10.1016/j.jfineco.2008.10.003

Iatridis, G. (2012). Hedging and earnings management in the light of IFRS implementation: Evidence from the UK stock market. The British Accounting Review, 44(1), 21-35. http://dx.doi.org/10.1016/j.bar.2011.12.002 
Ismail, W. A., Kamarudin, K. A., Van Zijl, T., \& Dunstan, K. (2013). Earnings quality and the adoption of IFRS-based accounting standards: Evidence from an emerging market. Asian Review of Accounting, 21(1), 53-73.

Jeanjean, T., \& Stolowy, H. (2008). Do accounting standards matter? An exploratory analysis of earnings management before and after IFRS adoption. Journal of Accounting and Public Policy, 28(6), 480-494.

Kim, J. B., \& Shi, H. (2012). IFRS reporting, firm-specific information flows, and institutional environments: International evidence. Review of Accounting Studies, 17(3), 474-517. http://link.springer.com/journal/volumesAndIssues/11142

Kim, J. B., Shi, H., \& Zhou, J. (2014). International financial reporting standards, institutional infrastructures, and implied cost of equity capital around the world. Review of Quantitative Finance and Accounting, 42(3), 469-507.

Kothari, S. P., Leone, A. J., \& Wasley, C. E. (2005). Performance matched discretionary accrual measures. Journal of Accounting and Economics, 39(1), 163-197.http://dx.doi.org/10.1016/j.jacceco.2004.11.002

Landsman, W. R., Maydew, E. L., \& Thornock, J. R. (2012). The information content of annual earnings announcements and mandatory adoption of IFRS. Journal of Accounting and Economics, 53(1-2), 34-54. http://dx.doi.org/10.1016/j.jacceco.2011.04.002

Leuz, C. (2003). IAS versus U.S. GAAP: Information-asymmetry based evidence from German's new market. Journal of Accounting Research, 41(3), 445-472.

Li, S. (2010). Does mandatory adoption of international financial reporting standards in the European union reduce the cost of equity capital? The Accounting Review, 85(2), 607-636. http://dx.doi.org/10.2308/accr.2010.85.2.607

Lobo, G. J., \& Zhou, J. (2006). Did conservatism in financial reporting increase after the Sarbanes Oxley Act?. Initial evidence. Accounting Horizons, 20(1), 57-73.

McInnis, J., \& Collins, D. W. (2011). The effect of cash flow forecasts on accrual quality and benchmark beating. Journal of Accounting and Economics, 51(3), 219-239.

Mouselli, S., Jaafar, A., \& Hussainey, K. (2012). Accruals quality vis-à-vis disclosure quality: Substitutes or complements? The British Accounting Review, 44(1), 36-46.http://dx.doi.org/10.1016/j.bar.2011.12.004

Paananen, M. (2008). The IFRS adoption's effect on accounting quality in Sweden. Available at SSRN 1097659.

Paananen, M., \& Lin, H. (2009). The development of accounting quality of IAS and IFRS over time: The case of Germany. Journal of International Accounting Research, 8(1), 31-55. http://dx.doi.org/10.2308/jiar.2009.8.1.31

Palea, V. (2009). The effects of the IAS/IFRS adoption in the European Union on the financial industry. Retrieved April 21, 2015, from http://ssrn.com/abstract $=1088712$

Rajgopal, S., \& Venkatachalam, M. (2011). Financial reporting quality and idiosyncratic return volatility. Journal of Accounting and Economics, 51(1-2), 1-20.http://dx.doi.org/10.1016/j.jacceco.2010.06.001

Ru, G., \& Baljit, S. (2018). Convergence of accounting standards and financial reporting externality: Evidence from mandatory IFRS adoption. Accounting \& Finance, 58(3), 817-848.

Ruland, W., Shon, J., \& Zhou, P. (2007). Effective controls for research in international accounting. Journal of Accounting and Public Policy, 26(1), 96-116.http://dx.doi.org/10.1016/j.jaccpubpol.2006.11.004

Schipper, K. (2005). The introduction of International Accounting Standards in Europe: Implications for international convergence. European Accounting Review, 14(1), 101-126. http://dx.doi.org/10.1080/0963818042000338013

Summers, S. L., \& Sweeney, J. T. (1998). Fraudulently misstated financial statements and insider trading: An empirical analysis. The Accounting Review, 73(1), 131-145.

Tsalavoutas, I., André, P., \& Evans, L. (2012). The transition to IFRS and the value relevance of financial statements in Greece. The British Accounting Review, 44(4), $262-277$. http://dx.doi.org/10.1016/j.bar.2012.09.004

Velury, U., \& Jenkins, D. (2006). Institutional ownership and the quality of earnings. Journal of Business Research, 59, 1043-51. 
Wang, J. W., \& Yu, W. W. (2015). The information content of stock prices, legal environments, and accounting standards: International evidence. European Accounting Review, 24(3), 471-493. http://dx.doi.org/10.1080/09638180.2014.977802

Wang, X., Young, G., \& Zhuang, Z. (2008). The effects of mandatory adoption of international financial reporting standards on information environments. Paper presented at the American Accounting Association meeting, Chicago, IL.

Watrin, C., \& Ullmann, R. (2012). Improving earnings quality: The effect of reporting incentives and accounting standards. Advances in Accounting, 28(1), 179-188.http://dx.doi.org/10.1016/j.adiac.2012.03.001

Watts, R., \& Zimmerman, J. (1978, January). Towards a positive theory of the determination of accounting standards. The Accounting Review, 53, 112-134.

\section{Appendix A}

\section{Robustness tests}

OLS Regression

\begin{tabular}{|l|l|l|l|l|}
\hline & & & & \\
\hline & coef. & std.err & $\mathrm{t}$ & $\mathrm{p}$ \\
\hline GROWTH_OPPORTUNITY & 0.00042 & 0.00016 & 2.57 & 0.01 \\
\hline LEVERAGE & 0.01942 & 0.00409 & 4.75 & 0 \\
\hline SIZE & -0.00211 & 0.000359 & -5.9 & 0 \\
\hline ROA & -0.06953 & 0.003303 & -21.05 & 0 \\
\hline IFRS & -0.0048 & 0.001498 & -3.21 & 0.001 \\
\hline Const & 0.08525 & 0.00431 & 19.78 & 0 \\
\hline
\end{tabular}

\section{VIF RESULTS}

\begin{tabular}{|l|r|l|}
\hline Variable & \multicolumn{1}{|l|}{ VIF } & \multicolumn{1}{l|}{ / VIF } \\
\hline Size & 1.18 & 0.849529 \\
\hline ROA & 1.17 & 0.855832 \\
\hline LEVERAGEZE N & 1.05 & 0.950574 \\
\hline $\begin{array}{l}\text { Growth } \\
\text { opportunity }\end{array}$ & 1.02 & 0.976008 \\
\hline IFRS & 1.02 & 0.982989 \\
\hline Mean VIF & 1.09 & \\
\hline
\end{tabular}

(Modified Johns Model) Fixed Effect Model

\begin{tabular}{|l|l|l|l|l|}
\hline & coef. & std.err & $\mathrm{t}$ & $\mathrm{P}$ \\
\hline GROWTH_OPPORTUNITY & 0.00022 & 0.000195 & 1.14 & 0.252 \\
\hline LEVERAGE & 0.005147 & 0.006573 & 0.78 & 0.434 \\
\hline SIZE & -0.0048 & 0.001399 & -3.46 & 0.001 \\
\hline ROA & -0.6382 & 0.004378 & -14.58 & 0 \\
\hline IFRS & -0.00717 & 0.001895 & -3.79 & 0 \\
\hline Const & 0.1222 & 0.01628 & 7.51 & 0 \\
\hline
\end{tabular}


(Johns Model) Fixed Effect Model with Adjusted Standard Error for Hetroscedasticity

\begin{tabular}{|c|c|c|c|c|}
\hline \multicolumn{3}{|l|}{ fe with robust std. err } & \multirow[b]{2}{*}{$\mathrm{t}$} & \multirow[b]{2}{*}{$\mathrm{p}$} \\
\hline & coef. & std.err & & \\
\hline GROWTH_OPPORTUNITY & 0.00022 & 0.00023 & 0.99 & 0.323 \\
\hline LEVERAGE & 0.00554 & 0.00696 & 0.8 & 0.426 \\
\hline SIZE & -0.00455 & 0.00169 & -2.69 & 0.007 \\
\hline $\mathrm{ROA}$ & -0.05838 & 0.00804 & -7.26 & 0 \\
\hline IFRS & -0.00678 & 0.00192 & -3.52 & 0 \\
\hline Const & 0.1171 & 0.0196 & 5.96 & 0 \\
\hline
\end{tabular}

(Johns Model) Fixed Effect Model

\begin{tabular}{|l|l|l|l|l|}
\hline & coef. & std.err & $\mathrm{t}$ & $\mathrm{p}$ \\
\hline GROWTH_OPPORTUNITY & 0.00022 & 0.000195 & 1.14 & 0.252 \\
\hline LEVERAGE & 0.00514 & 0.006573 & 0.74 & 0.434 \\
\hline SIZE & -0.0048 & 0.001399 & -3.46 & 0.001 \\
\hline ROA & -0.0638 & 0.004378 & -14.58 & 0 \\
\hline IFRS & -0.00717 & 0.001896 & -3.79 & 0 \\
\hline const & 0.12225 & 0.01628 & 7.51 & 0 \\
\hline
\end{tabular}

\section{Copyrights}

Copyright for this article is retained by the author(s), with first publication rights granted to the journal.

This is an open-access article distributed under the terms and conditions of the Creative Commons Attribution license (http://creativecommons.org/licenses/by/4.0/). 